\title{
ALTERNATIVE PRODUCTS TO CONTROL Sclerotinia sclerotiorum IN SOYBEAN
}

\author{
PRODUTOS ALTERNATIVOS NO CONTROLE DE Sclerotinia sclerotiorum NA \\ CULTURA DA SOJA
}

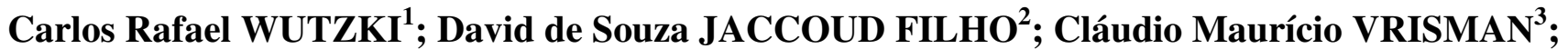
Fernando Cezar JULIATTI ${ }^{4}$; Aguinaldo José do NASCIMENTO ${ }^{5}$

1. Engenheiro Agrônomo, Doutorando em Agronomia, Universidade Estadual de Ponta Grossa - UEPG, Ponta Grossa, PR, Brasil. 2. Biólogo, Engenheiro Agrônomo, Professor, Doutor, Departamento de Fitotecnia e Fitossanidade - DEFITO - UEPG - Ponta Grossa, PR, Brasil. Dj1002@uepg.br; 3. Engenheiro Agrônomo, UEPG, Ponta Grossa, PR, Brasil; 4. Engenheiro Agrônomo, Professor, Doutor, Instituto de Ciências Agrárias - ICIAG, Universidade Federal de Uberlândia - UFU, Uberlândia, MG, Brasil; 5. Engenheiro Agrônomo, Professor Aposentado, Doutor, Departamento de Bioquímica, Universidade Federal do Paraná - UFPR.
\end{abstract}

\begin{abstract}
The aim of this study was to evaluate different alternative products, foliar sprayed either alone or in combination with fungicide fluazinam, to control white mold in soybean at three locations: Arapoti, Mauá-da-Serra, and Pinhão, in Paraná state, southern Brazil. The following chemical products were used: sodium dichloroisocyanurate, benzalkonium chloride, pyroligneous extract, sodium hypochlorite, cobalt + molybdenum, sucrose, sodium bicarbonate and acibenzolar-S-methyl. Incidence, severity, yield, and number of sclerotia produced were analyzed. The majority of the variables did not follow the normal distribution of the data according to the Kolmogorov-Smirnov test; therefore, the use of non-parametric analysis was necessary. The analysis of all the treatments individually revealed no significant effects so it was decided to separate the analysis into the following groups of treatments: 'control', treatments using alternative products ('alternatives'), treatment only with fungicide ('fungicide') and treatments with alternative products and fungicide ('alternatives + fungicide'). In Arapoti, no significant differences for any variables were observed. In Mauá-daSerra, the 'fungicide' and 'alternatives + fungicide' had the lowest incidence and number of sclerotia, with higher yield when compared to 'control' and 'alternatives'. No differences were observed for severity. In Pinhão, the 'fungicide' and 'alternatives + fungicide' were superior for incidence, number of sclerotia produced, and yield when compared to the 'control' and 'alternatives'. The 'alternatives + fungicide' showed significantly lower severity when compared to the control, 'alternatives' and 'fungicide' in Pinhão experiment. In conclusion, the alternative products applied in combination with fluazinam resulted in lower severity of white mold in soybean in the experiment conducted in Pinhão, and the application of fluazinam alone or in combination with alternative products, was efficient to control white mold in soybean in locations with high disease incidence.
\end{abstract}

KEYWORDS: White mold. Glycine $\max$ (L.) Merrill. Household cleaning products. Chlorine. Induced resistance.

\section{INTRODUCTION}

Soybean (Glycine max (L.) Merril) is considered one of the most important Fabaceae in the world; it is used as a source of protein for human and animal consumption and also as raw material for oil extraction for food. It is also used in biodiesel production and in countless processed and semiprocessed products. Due to these nutritional and industrial characteristics, and its great adaptability to different climates and soils, soybean is one of the major plants cultivated worldwide. Brazil is the second largest producer on a global scale, with an average yield of $2.882 \mathrm{~kg} \mathrm{ha}^{-1}$ (CONAB, 2014). Several factors may limit productivity, such as the presence of diseases that can cause significant economic losses. One of these is white mold, caused by the fungus Sclerotinia sclerotiorum (Lib.) de Bary. This soilborne pathogen can infect more than 400 plant species (BOLAND; HALL, 1994), and it can be responsible for severe losses when conditions are conducible for its development. Under these conditions, soybean crops have suffered losses up to $70 \%$, as reported by Jaccoud Filho et al. (2010) in the 2008-2009 crop season in the southern Brazilian state of Paraná.

In order to minimize the damage of white mold in soybean, a set of preventive measures should be adopted, such as the use of pathogen-free seeds, seed treatment, the correct application timing for products, density and spacing of seeding, mulching, crop rotation, the use of biological control agents, alternative products and fungicides (GÖRGEN et al., 2009; HENNEBERG et al., 2012; JACCOUD FILHO et al, 2010; SILVA et al, 2010; ZENG et al., 2012). The use of fungicides have the potential to cause environmental and food contamination. In order to minimize the environmental impact of the chemical products usage, more research is required regarding the use 
of products with low toxicity to humans and lower potential of environmental impact (SMILANICK et al., 1999; WALTER et al., 2009) as it is the case of the alternative products used in this study.

The aim of this study was to assess the effectiveness of different alternative products, applied either alone or in combination with fungicide fluazinam, in the management of white mold in soybean under field conditions.

\section{MATERIAL AND METHODS}

Three experiments were conducted in areas naturally infested by white mold in the 2011-12 crop season in the municipalities of Arapoti, Mauá-daSerra and Pinhão, all located in the southern state of Paraná, Brazil, and conducted under no-tillage system.
Soil was collected to quantify the number of sclerotia in four points of $0.25 \mathrm{~m}^{-2}$ at a depth of 5 $\mathrm{cm}$, following the methodology proposed by Jaccoud Filho et al. (2010). In Arapoti, 55 sclerotia $\mathrm{m}^{-2}$ were found; in Mauá-da-Serra, 452 sclerotia $\mathrm{m}^{-2}$, and in Pinhão, 149 sclerotia $\mathrm{m}^{-2}$. In Arapoti the soybean cultivar used was BMX Turbo RR, sown on $11 / 27 / 2011$ with 16 seeds $\mathrm{m}^{-1}$. In Mauá-da-Serra, NA5909 RR, sown on 10/30/2011 with 14 seeds m $^{-1}$, and in Pinhão, BMX Apollo RR, sown on $11 / 10 / 2011$ with 12 seeds $\mathrm{m}^{-1}$. The seeds were treated with pyraclostrobin, thiophanate methyl and fipronil at the dosage of 5, 45 and 50 grams of active ingredient per $100 \mathrm{~kg}$ of seeds, respectively. In all three sites the spacing used was $45 \mathrm{~cm}$ between rows. The experimental design was a randomized block design with 18 treatments and four replications (Table 1). The plots were $3.0 \mathrm{~m}$ wide and $5.0 \mathrm{~m}$ long, with a total area of $15.0 \mathrm{~m}^{2}$.

Table 1. Treatments, phenological stages of applications, and doses used in the experiments of the alternative control of white mold in soybean, conducted in Arapoti, Mauá-da-Serra and Pinhão, PR. 2011-12 crop season.

\begin{tabular}{|c|c|c|c|c|c|c|}
\hline \multirow{2}{*}{\multicolumn{2}{|c|}{ Treatments }} & \multicolumn{4}{|c|}{ Applications } & \multirow{3}{*}{$\begin{array}{l}\text { Dosage ha }^{-1} \\
\text { - }\end{array}$} \\
\hline & & \multirow{2}{*}{$\frac{1^{\mathrm{st}}}{-}$} & \multirow{2}{*}{$\frac{2^{\text {nd }}}{-}$} & \multirow{2}{*}{$\frac{3^{\text {rd }}}{-}$} & \multirow{2}{*}{$\frac{4^{\text {th }}}{-}$} & \\
\hline 1 & control & & & & & \\
\hline 2 & cobalt $(1 \%)+$ molybdenum $(5 \%)$ & $\mathrm{V} 4^{2}$ & $\mathrm{~V} 9^{3}$ & $\mathrm{R} 1^{4}$ & $10 \mathrm{DAA}^{5}$ & 0.3 L c.p. ${ }^{6}$ \\
\hline 3 & sucrose $(98 \%)$ & V4 & V9 & R1 & 10 DAA & 2 kg c.p. \\
\hline 4 & bicarbonate of soda & V4 & V9 & R1 & 10 DAA & 2 kg c.p. \\
\hline 5 & sodium dichloroisocyanurate (70\%) & V4 & V9 & $\mathrm{R} 1$ & 10 DAA & 66 g c.p. \\
\hline 6 & benzalkonium chloride (12.5\%) & $\mathrm{V} 4$ & V9 & $\mathrm{R} 1$ & $10 \mathrm{DAA}$ & 1 L c.p. \\
\hline 7 & pyroligneous extract & V4 & V9 & $\mathrm{R} 1$ & 10 DAA & $1 \mathrm{~L}$ c.p. \\
\hline 8 & sodium hypochlorite $(2.5 \%)$ & V4 & V9 & R1 & 10 DAA & 2 L c.p. \\
\hline 9 & acibenzolar-S-methyl (50\%) & V4 & V9 & $\mathrm{R} 1$ & 10 DAA & 25 g c.p. \\
\hline 10 & fluazinam & - & - & $\mathrm{R} 1$ & $10 \mathrm{DAA}$ & $0.5 \mathrm{~kg}$ g.a.i. ${ }^{7}$ \\
\hline \multirow{2}{*}{11} & cobalt $(1 \%)+$ molybdenum $(5 \%)$ & V4 & V9 & - & - & 0.3 L c.p. \\
\hline & fluazinam & - & - & $\mathrm{R} 1$ & 10 DAA & 0.5 kg g.a.i. \\
\hline \multirow{2}{*}{12} & sucrose $(98 \%)$ & V4 & V9 & - & - & 2 kg c.p. \\
\hline & fluazinam & - & - & $\mathrm{R} 1$ & $10 \mathrm{DAA}$ & $0.5 \mathrm{~kg}$ g.a.i. \\
\hline \multirow{2}{*}{13} & bicarbonate of soda & V4 & V9 & - & - & 2 kg c.p. \\
\hline & fluazinam & - & - & $\mathrm{R} 1$ & 10 DAA & $0.5 \mathrm{~kg}$ g.a.i. \\
\hline \multirow{2}{*}{14} & sodium dichloroisocyanurate (70\%) & V4 & V9 & - & - & 66 g c.p. \\
\hline & fluazinam & - & - & $\mathrm{R} 1$ & $10 \mathrm{DAA}$ & $0.5 \mathrm{~kg}$ g.a.i. \\
\hline \multirow{2}{*}{15} & benzalkonium chloride (12.5\%) & V4 & V9 & - & - & 1 L c.p. \\
\hline & fluazinam & - & - & R1 & 10 DAA & $0.5 \mathrm{~kg}$ g.a.i. \\
\hline
\end{tabular}




\begin{tabular}{llccccc}
\hline \multirow{2}{*}{16} & pyroligneous extract & V4 & V9 & - & - & 1 L c.p. \\
\cline { 2 - 7 } & fluazinam & - & - & R1 & 10 DAA & 0.5 kg g.a.i. \\
\hline \multirow{2}{*}{17} & sodium hypochlorite $(2.5 \%)$ & V4 & V9 & - & - & 2 L c.p. \\
\cline { 2 - 7 } & fluazinam & - & - & R1 & 10 DAA & 0.5 kg g.a.i. \\
\hline \multirow{2}{*}{18} & acibenzolar-S-methyl $(50 \%)$ & V4 & V9 & - & - & 25 g c.p. \\
\cline { 2 - 7 } & fluazinam & - & - & R1 & 10 DAA & 0.5 kg g.a.i. \\
\hline
\end{tabular}

-: not applicable; ${ }^{1}$ ha: hectare ${ }^{2} \mathrm{~V} 4: 4$ open trifoliates; ${ }^{3} \mathrm{~V} 9: 9$ open trifoliates; ${ }^{4} \mathrm{R} 1$ : first open flower; ${ }^{5} 10$ DAA: 10 days after R1; ${ }^{6}$ c.p.: commercial product; ${ }^{7}$ g.a.i.: grams of the active ingredient.

The applications were conducted using a pressurized $\mathrm{CO}_{2}$ backpack sprayer, with a pressure of 3 bars and a 6 nozzle spray boom (3.0 m length) using Teejet ${ }^{\circledR}$ XR 11002 fan type spray nozzles and a volume of liquid of $200 \mathrm{~L} \mathrm{ha}^{-1}$.

The assessment of incidence and severity of plants infected by S. sclerotiorum was performed in 100 plants in the two central rows of each plot when the soybean was at R5.5 phenological stage (pods with $75-100 \%$ graining). For the assessment of severity, the diagrammatic scale proposed by Juliatti and Juliatti (2010) was used.

Prior to harvest, eight infected plants were marked in the central rows of each plot and these were subsequently collected using plastic bags to quantify the number of sclerotia produced in laboratory. From these data, and the incidence of the disease in the plots, it was possible to estimate the production of sclerotia ha ${ }^{-1}$ for each treatment.

For yield evaluation, four meters in length were harvested by hand, using the four central rows of each plot, (7.2 $\mathrm{m}^{2}$ total). The harvested area was threshed with a motorized grain mixer and moisture was adjusted to $13 \% \mathrm{v} / \mathrm{v}$. All the data were tested for normality using the Kolmogorov-Smirnov test and submitted to the nonparametric Kruskal-Wallis and Mann-Whitney-U tests, using Statistica $10.0 ®$ (Statsoft ${ }^{\circledR}$ ) software.

Meteorological data were provided by the stations of SIMEPAR (Meteorological System of Paraná) the ones that have the nearest location to the experiments.

\section{RESULTS AND DISCUSSION}

The statistical analysis showed that most of the variables did not follow the normal distribution of the data, according to the Kolmogorov-Smirnov test; consequently, the use of non-parametric tests was necessary. The analysis of all the treatments individually revealed no significant effects so it was decided to separate the analysis into the following four treatment groups: one treatment without the application of products ('control'); treatments 2 to 9 , which included all the alternative products applied individually ('alternatives' group); treatment 10 , which consisted of the isolated application of the fungicide fluazinam ('fungicide' group); and treatments 11 to 18 , which consisted of fungicide applied together with alternative products ('alternatives + fungicide' group). No differences were found between the treatments within the same group.

\section{Arapoti}

In the experiment conducted in Arapoti, a lower incidence (12.5\% in the 'control' - Figure 1A) and intermediate severity $(69.1 \%$ in the 'control' Figure 1B) of $S$. sclerotiorum were detected, compared with the severity detected in the experiments conducted in Mauá-da-Serra $(65.3 \%$ in the control - Figure 2) and Pinhão (84.3\% in the control - Figure 3). This was probably due to the low rainfall during flowering of the crop in the region of Arapoti. In the 20 days after the appearance of the first flowers there was a total of $20 \mathrm{~mm}$ rainfall, a decrease in relative humidity to approximately $76 \%$, and an air average temperature of $20^{\circ} \mathrm{C}$ (Appendix A).

On average, the cultivars used in the three trials had flowering periods of approximately 20 days. Meteorological data for this period were monitored because flowering is the period of greatest susceptibility to infection by $S$. sclerotiorum. The climatic conditions during the flowering period are crucial for the occurrence of white mold in soybean because the flowers are used as primary energy source for the germination of the ascospore. Free water on the plants surface is necessary for the infection to occur (ABAWI; GROGAN, 1979; NAPOLEÃO et al., 2005).

In Arapoti no difference was found in any of the analyzed variables (Figure 1), occur possibly due to the low recorded incidence of white mold (Figure 1A). This fact generated a large variation in the data, as can be seen by the error bars (Figure 1). Because of this, non-parametric statistical analysis on the data set still resulted in limitations in the 
sensitivity of the analysis (Figure 1A and 1C). The 'alternatives', 'fungicide' and 'alternatives + fungicide' groups showed a reduction of 34.4, 44.0 and $53.6 \%$ in the incidence, and 48.7; 53.7 and $52.7 \%$ in the production of sclerotia, respectively.

(A)

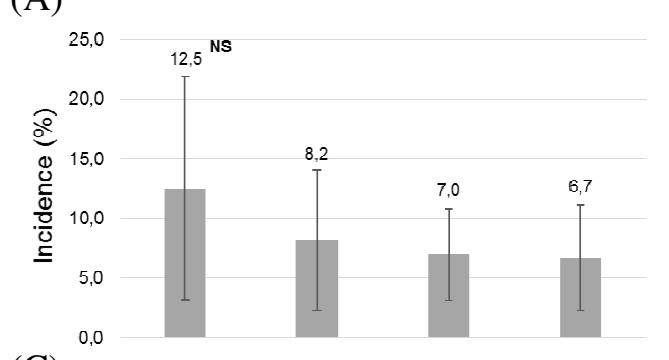

(C)

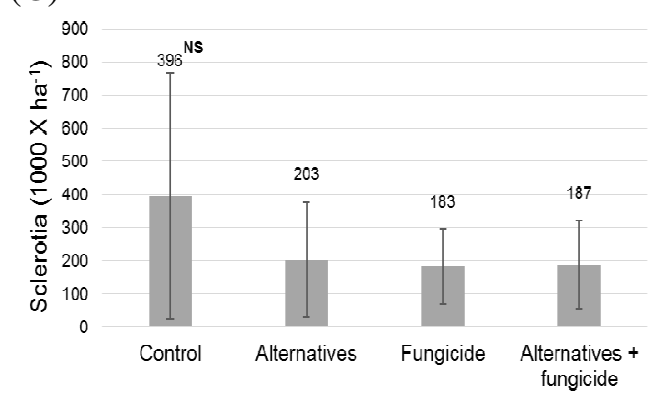

These absolute values can be significant in a long term management of this disease, because it is a pathogen that is difficult to control and it produces resistant structures (sclerotia) that remain viable in the soil for many years.

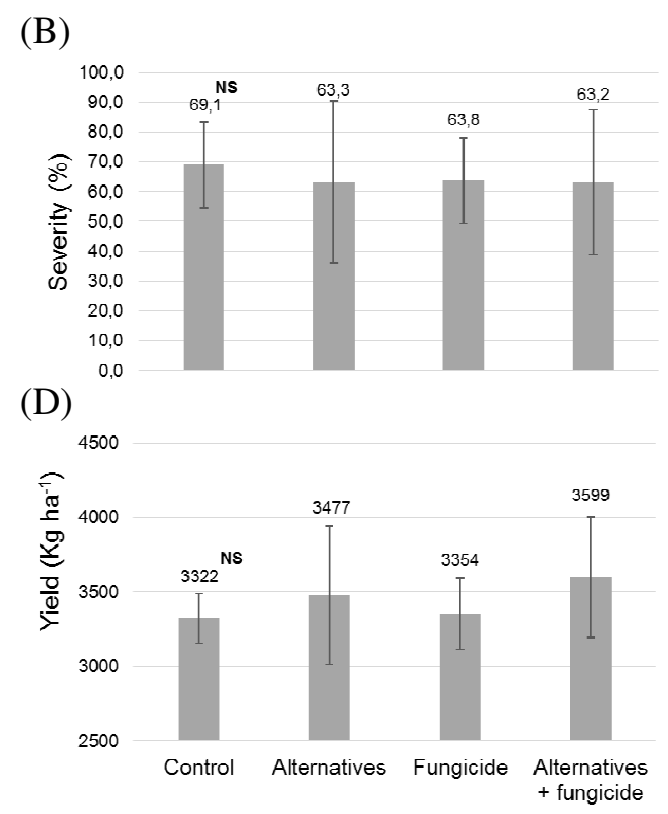

Figure 1. Data from the experiment conducted in Arapoti, PR in the 2011-12 crop. A - average incidence of S. sclerotiorum (NS: no statistically significant difference - Kruskal-Wallis $p=0.241$ ); B - Average severity of plants infected by $S$. sclerotiorum (Kruskal-Wallis $\mathrm{p}=0.241$ ); C - Number of sclerotia ha $^{-1}$ (Kruskal-Wallis, $\left.\mathrm{p}=0.427\right)$; $\mathrm{D}-$ yield in $\mathrm{kg} \mathrm{ha}^{-1}$ (Kruskal-Wallis, $\left.\mathrm{p}=0.371\right)$. The error bar represents the standard deviation.

\section{Mauá-da-Serra}

In Mauá-da-Serra the highest incidence of $S$. sclerotiorum (27\% in the 'control' - Figure $2 \mathrm{~A}$ ) and the lowest values for severity $(65.3 \%$ in the control - Figure 2B) were observed, when compared with Arapoti $(12.5 \%$ incidence and $69.1 \%$ severity in the control - Figure 1) and Pinhão (20.5\% incidence and $84.3 \%$ and severity in the control - Figure 3). This may be explained by the high level of contamination in the area (452 sclerotia $\mathrm{m}^{-2}$ ), high rainfall (107 $\mathrm{mm}$ ), average air humidity of $82 \%$ and an average temperature of $21.6^{\circ} \mathrm{C}$ during the 20 days after flowering (Appendix B).

The 'fungicide' and 'alternatives + fungicide' groups showed lower incidence of white mold (Figure 2A), with a control of 81.5 and $77.7 \%$, respectively, when compared to the 'control' group. However, no statistically significant differences were observed for severity (Figure 2B).

The low incidence values (Figure 2A) observed for 'fungicides' and 'alternatives + fungicide' reflected in a low production of sclerotia (Figure 2C) and in a higher crop yield (Figure 2D), which significantly differed from the 'control' and 'alternatives'.
These results demonstrate that in areas with history occurrence, and high contamination of $S$. sclerotiorum it is necessary to use fungicide treatment to decrease the production of survival structures, which will affect subsequent crops. This use will also result in crop yield increase, which will cover the costs of acquisition and application of fungicide, thereby maintaining profitability for growers. It is noteworthy that the control of white mold in soybean should be performed considering a combination of several strategies and not based exclusively on the fungicides application.

\section{Pinhão}

In the experiment conducted in Pinhão (Figure 3 ), the incidence was intermediate $(20.3 \%$ in the control - Figure 3A) but with high severity (84.3\% in the control - Figure 3B) compared to Mauá-da-Serra (27\% incidence and $65.3 \%$ severity in the control - Figure 2) and Arapoti (12.5\% incidence and $69.1 \%$ severity in the control - Figure $1)$. 
(A)

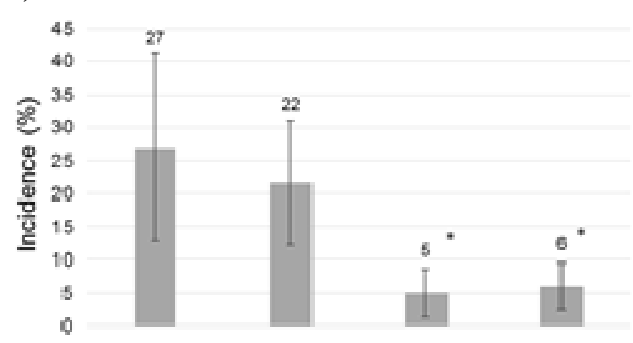

(C)

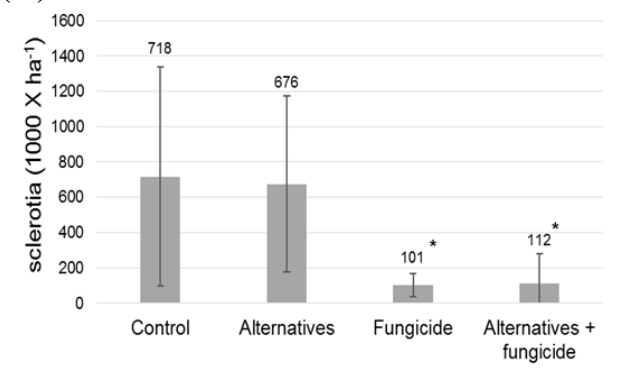

(B)

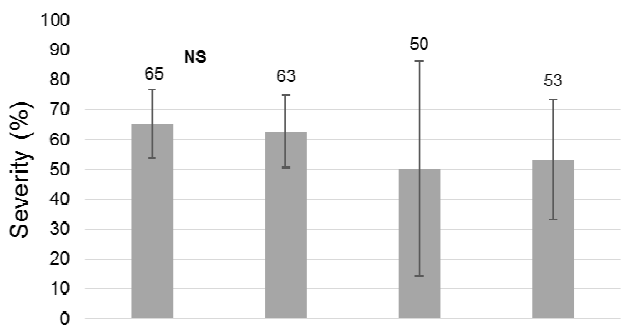

(D)

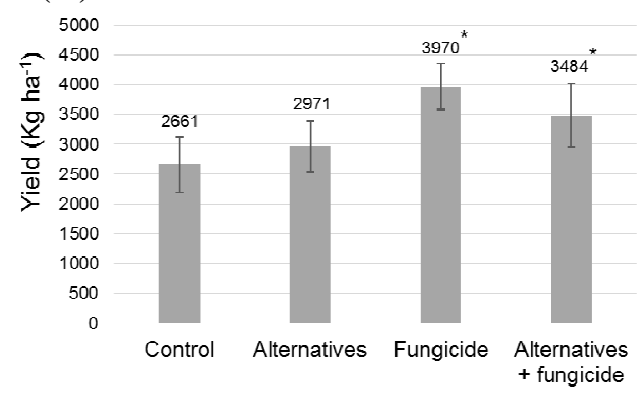

Figure 2. Data from the experiment conducted in Mauá-da-Serra,PR 2011-12 crop. A - Average incidence of $S$. sclerotiorum (* statistically significant difference with control and 'alternatives' groups - MannWhitney-U, $\mathrm{p}<0.05$ ); B - Average severity of plants infected by S. sclerotiorum (NS: no statistically significant difference (Kruskal-Wallis $\mathrm{p}=0.973$ ), $\mathrm{C}$ - number of sclerotia ha ${ }^{-1}$ Mann-Whitney-U, $\mathrm{p}<$ 0.05);. D - yield in $\mathrm{kg} \mathrm{ha}^{-1}$ Mann-Whitney-U, $\left.\mathrm{p}<0.05\right)$. The error bar represents the standard deviation.

(A)

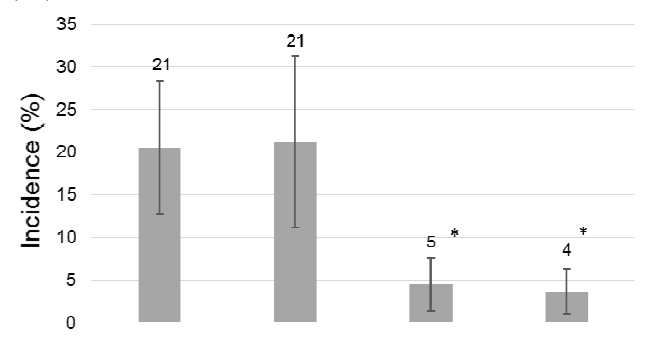

(C)

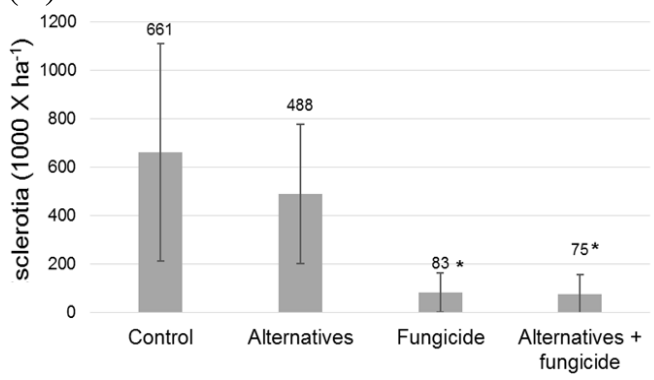

(B)

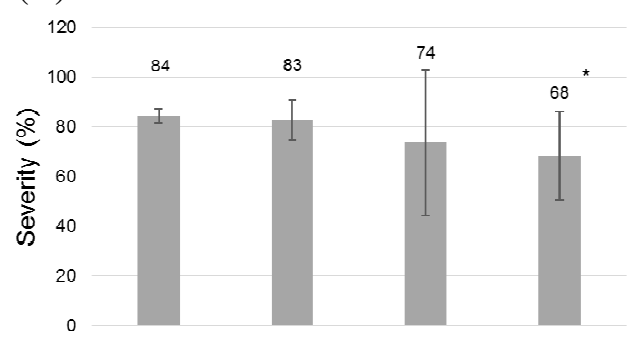

(D)

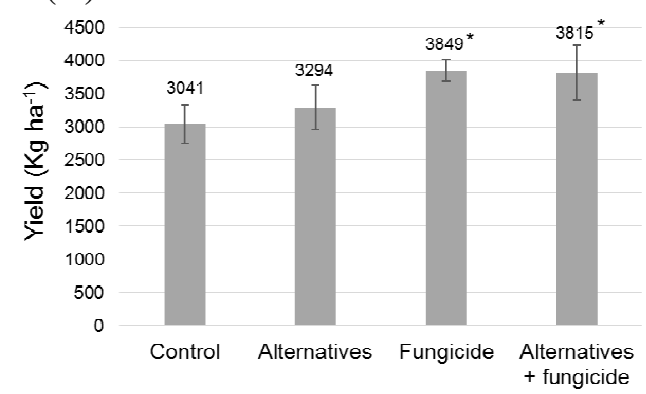

Figure 3. Data from the experiment conducted in Pinhão, PR, 2011-12 crop. A - Average incidence of $S$. sclerotiorum (* statistically significant difference with control and 'alternatives' groups - MannWhitney-U, p < 0.05); B - Average severity of plants infected by S. sclerotiorum Mann-Whitney-U, $\mathrm{p}<0: 05) ; \mathrm{C}$ - number of sclerotia $\mathrm{ha}^{-1}$ Mann-Whitney-U, $\left.\mathrm{p}<0.05\right)$; D - Yield in $\mathrm{kg} \mathrm{ha}^{-1}$ MannWhitney-U, $\mathrm{p}<0.05)$. The error bar represents the standard deviation. 
The lower incidence in the region of Pinhão may have possibly been due to the lower initial inoculum (149 sclerotia $\mathrm{m}^{-2}$ ) compared to Mauá-daSerra (452 sclerotia $\mathrm{m}^{-2}$ ). However, the higher severity in Pinhão may be explained by the higher rainfall $(132 \mathrm{~mm})$ that occurred during the 20 daysflowering, average air humidity of $80 \%$ and average air temperature of $21.3^{\circ} \mathrm{C}$, which provided a conducive environment for disease development (Appendix C) (AGRIOS, 2005; COLEY-SMITH; COOKE, 1971; MORAL, 1977).

Data show the effectiveness of the 'fungicide' and 'alternatives + fungicide' in reducing the incidence of white mold in soybean (78.1 and $82.4 \%$, respectively) (Figure 3A). There was no difference between the 'control' and 'alternatives' groups. Regarding the severity of white mold, the 'alternatives + fungicide' group was statistically lower when compared to the 'control', 'alternatives' and 'fungicide' groups, with a reduction of $18.8,17.4$ and $7.2 \%$, respectively (Figure 3B).

Similarly to the results observed in Mauáda-Serra, control provided by 'fungicide' on its own or 'alternatives + fungicide' was observed for incidence. That reflected in a significant reduction in the production of sclerotia (Figure 3C), with a decrease of 87.5 and $88.6 \%$, when compared to the 'control' group, respectively. These values are extremely important regarding the long term management of white mold in infested areas, due to the lengthy persistence of viable sclerotia in the soil and the limitation of crops for rotation. This represents another strategy to be used, as it provides incremental yield, which can be seen in Figure 3D where the 'fungicide' and 'alternatives + fungicide' were comparatively different from the control and 'alternatives', with 26.6 and $25.4 \%$ increment in yield when compared to the 'control', respectively.

These results emphasize the importance of the fungicide use, combined or not with alternative products, in areas with medium-high inoculum potential, for both increase on yields and decrease on production of sclerotia for subsequent crops. It is evident that the use of alternative products provided a significantly lower severity in the 'alternatives + fungicide' group when compared to the other groups in Pinhão, where the use of alternative product possibly had a negative effect on the development of the pathogen. This result is very important because the isolated use of the fungicide resulted in lower levels of incidence in Mauá-da-Serra (Figure 2A) and Pinhão (Figure 3A) but there were no differences for severity in these two locations.

There have been reports of the successful use of alternative products tested for several pathogens, such as the control of Penicillium digitatum in citrus fruits using sodium bicarbonate (SMILANICK et al., 1999.); the disinfestation of green coconuts using sodium hypochlorite (WALTER; NASCIMENTO; KUAYE, 2009); and the decontamination of plants for in vitro cultivation using sodium dichloroisocyanurate (PARKINSON; PRENDERGAST; SAYEGH, 1996) among others.

The results obtained at Pinhão trial (Figure 3 B), disagree with those obtained by Sumida (2012), who found no statistical differences between the applications of fungicide in isolation, or mixed with benzalkonium chloride, on the severity of white mold in soybean. However, Sumida did not observe statistically significant differences in the incidence of white mold in soybean using the fungicide fluazinam together (or not) with benzalkonium chloride, which were similar to the results observed for incidence in all three locations used in this experiment (Figure 1A, 2A and 3A).

There is little research on the use of alternative products to manage white mold in soybean that can be used as reference for discussion, which emphasizes the importance of this study in a field that still lacks information.

\section{CONCLUSIONS}

The alternative products that were applied in combination with the fungicide fluazinam resulted in reduced severity of white mold in soybean in the experiment conducted in Pinhão, PR.

The application of fluazinam, either alone or in combination with alternative products, was effective in reducing white mold incidence and sclerotia production in Mauá-da-Serra and Pinhão, with yield increase for both locations.

\section{ACKNOWLEDGEMENTS}

The authors would like to thank the Coordination for the Improvement of Higher Education Personnel (CAPES) for granting an MA scholarship to the first named author and for the financial support contained in research grant 064/2008 CNPq/MAPA.

RESUMO: O objetivo deste estudo foi avaliar diferentes produtos alternativos pulverizados via foliar, isoladamente ou em combinação com o fungicida fluazinam para o controle do mofo branco na cultura da soja, em três 
locais: Arapoti, PR, Mauá-da-Serra, PR e Pinhão, PR, Brasil. Os produtos utilizadas foram: dicloroisocianurato de sódio, cloreto de benzalcônio, extrato pirolenhoso, hipoclorito de sódio, cobalto + molibdenio, sacarose, bicarbonato de sódio e acibenzolar-S-metil. As variáveis analisadas foram incidência, severidade, rendimento e o número de escleródios produzidos. A maioria das variáveis não segue a distribuição normal dos dados conforme o teste Kolmogorov-Smirnov, assim sendo, o uso de testes não-paramétricos se fez necessário. A análise de todos os tratamentos individualmente não revelou efeitos significativos, onde optou-se por separar a análise em grupos de tratamentos, onde a testemunha foi denominada "controle"; os tratamentos com os produtos alternativos como "alternativos", o tratamento com o fungicida isolado como "fungicida" e os tratamentos com produtos alternativos e fungicida foi denominado "alternativos + fungicidas". Em Arapoti, não foram observadas diferenças estatisticamente significantes em nenhuma das variáveis analisadas. Em Mauá-da-Serra, os grupos 'fungicida' e 'alternativos + fungicida', apresentaram a menor incidência e número de escleródios, com maior rendimento quando comparados aos grupos 'controle' e 'alternativos'. Não foram observadas diferenças na severidade. Em Pinhão, os grupos 'fungicida' e 'alternativos + fungicida' foram estatisticamente superiores para incidência, número de escleródios produzidos e rendimento, quando comparados aos grupos 'controle' e 'alternativos'. O grupo 'alternativo + fungicida' apresentou severidade significativamente menor quando comparado aos grupos 'controle', 'alternativos' e 'fungicida' no experimento conduzido em Pinhão. Como conclusões, observou-se que os produtos alternativos aplicados em associação com o fungicida fluazinam proporcionaram menor severidade do mofo branco na cultura da soja no experimento conduzido em Pinhão, PR, e a aplicação do fungicida fluazinam isolado ou em associação com os produtos alternativos foi eficiente no controle do mofo branco na cultura da soja nos locais com alta incidência da doença. resistência.

PALAVRAS-CHAVE: Mofo-branco. Glycine $\max$ (L.) Merrill. Produtos domissanitários. Cloro. Indutor de

\section{REFERENCES}

ABAWI, G. S.; GROGAN. Epidemiology of diseases caused by Sclerotinia species. The American Phytophatological Society, Saint Paul, v. 69, n. 8, 1979.

AGRIOS, G. Plant Pathology, 5 ed. California: Academic Press, 2005.

BOLAND, G. J.; HALL, R. Epidemilogy of Sclerotinia Stem Rot on Soybean in Ontario. The American Phytophatological Society, Saint Paul, v. 78, n. 9, p. 1241-1245, 1988.

COLEY-SMITH, J. R.; COOKE. R. C. Survival and germination of fungal sclerotia. Annual Review of Phytopathology, Saint Paul, v. 9, p. 65-92, 1971. http://dx.doi.org/10.1146/annurev.py.09.090171.000433

COMPANHIA NACIONAL DE ABASTECIMENTO (CONAB). Brasil., Acompanhamento da safra brasileira de grãos 2013/2014. Oitavo Levantamento - Maio de 2014, Brasília. Disponível em: <

http://www.conab.gov.br/OlalaCMS/ uploads/arquivos /14_05_08_10_11_00_boletim_graos_maio_2014.pdf> Acesso em 10 mai. 2014.

GÖRGEN, C. A.; SILVEIRA NETO, A. N.; CARNEIRO, L. C.; RAGAGNIN, V. A.; LOBO JUNIOR, M. Controle do mofo-branco com palhada e Trichoderma harzianum 1306 em soja. Pesquisa Agropecuária Brasileira, Brasília, v. 44, p. 1583-1590, 2009. http://dx.doi.org/10.1590/S0100-204X2009001200004

HENNEBERG, L.; GRABICOSKI, E. M. G.; JACCOUD-FILHO, D. S; PANOBIANCO, M. Incidência de Sclerotinia sclerotiorum em sementes de soja e sensibilidade dos testes de detecção. Pesquisa Agropecuária Brasileira. Brasília, v. 47, n. 6, p. 763-768, jun. 2012.

JACCOUD FILHO, D. S.; MANOSSO NETO, M. O.; VRISMAN, C. M.; HENNEBERG, L.; GRABICOSKI, E. M. G.; PIERRE, M. L. C.; BERGER NETO, A.; SARTORI, F. F.; DEMARCH, V. B.; ROCHA, C. H. Análise, distribuição e quantificação do "Mofo Branco" em diferentes regiões produtoras do estado do Paraná. (Resumo). In: XXXI Reunião de Pesquisa de Soja da Região Central do Brasil - Resumos. Londrina: Embrapa Soja, 2010. p. 226 - 228. 
JULIATTI, F. C.; JULIATTI, F. C. A. Podridão branca da haste da soja: manejo e uso de fungicidas em busca da sustentabilidade nos sistemas de produção. Uberlândia: Composer, 33 p. 2010.

MORRAL, R. A. A. A preliminary study of the influence of water potential on sclerotium germination in Sclerotinia sclerotiorum. Canadian Journal Botany, Ottawwa, v. 55, p. 8-11, 1977.

NAPOLEÃO, R.; CAFÉ FILHO, A. C.; NASSER, L. C. B.; LOPES, C. A.; SILVA, H. R. Intensidade do mofo-branco do feijoeiro em plantio convencional e direto sob diferentes lâminas d'água. Fitopatologia Brasileira, Brasília, v. 30, p. 374-379, 2005. http://dx.doi.org/10.1590/s0100-41582005000400006

PARKINSON, M.; PRENDERGAST, M; SAYEGH, A. J. Sterilisation of explants and cultures with sodium dichloroisocyanurate. Plant Growth Regulation, Dordrecht, v. 20, p. 61-66, 1996.

http://dx.doi.org/10.1007/BF00024060

SILVA, J. I. C.; FERNANDES, D. M; PEREIRA, M. R. R; LÉLES, E. P; PEREIRA, F. R. S e CRUZ, S. C. S. Interferência do hipoclorito de sódio na absorção de macro e micronutrientes nas culturas da soja e do feijão.

Bioscience Journal, Uberlândia, v. 26, n. 2, p. 257-265, Mar/Apr. 2010.

SMILANICK, J. L.; MARGOSAN, D. A.; USALL, J.; MICHAEL, F. Control of citrus green mold by carbonate and bicarbonate salts and the influence of commercial postharvest practices on their efficacy. Plant Disease, Saint Paul, v. 83, p. 139-145, 1999. http://dx.doi.org/10.1094/PDIS.1999.83.2.139

SUMIDA, C. H. Controle do Mofo Branco na Cultura da Soja. 81 f. Tese (Doutorado em Agronomia), Universidade Estadual de Londrina, Londrina, 2012.

WALTER, E. H. M; NASCIMENTO, M. S; KUAYE, A. Y. Efficacy of sodium hypochlorite and peracetic acid in sanitizing green coconuts. Letters in Applied Microbiology, Oxford, v. 49, p. 366-371, 2009. http://dx.doi.org/10.1111/j.1472-765X.2009.02670.x

ZENG, W.; WANG, D.; KIRK, W.; HAO, J. Use of Coniothyrium minitans and other microorganisms for reducing Sclerotinia sclerotiorum. Biological Control, Orlando, v. 60, n. 2, p. 225-232, 2012. 


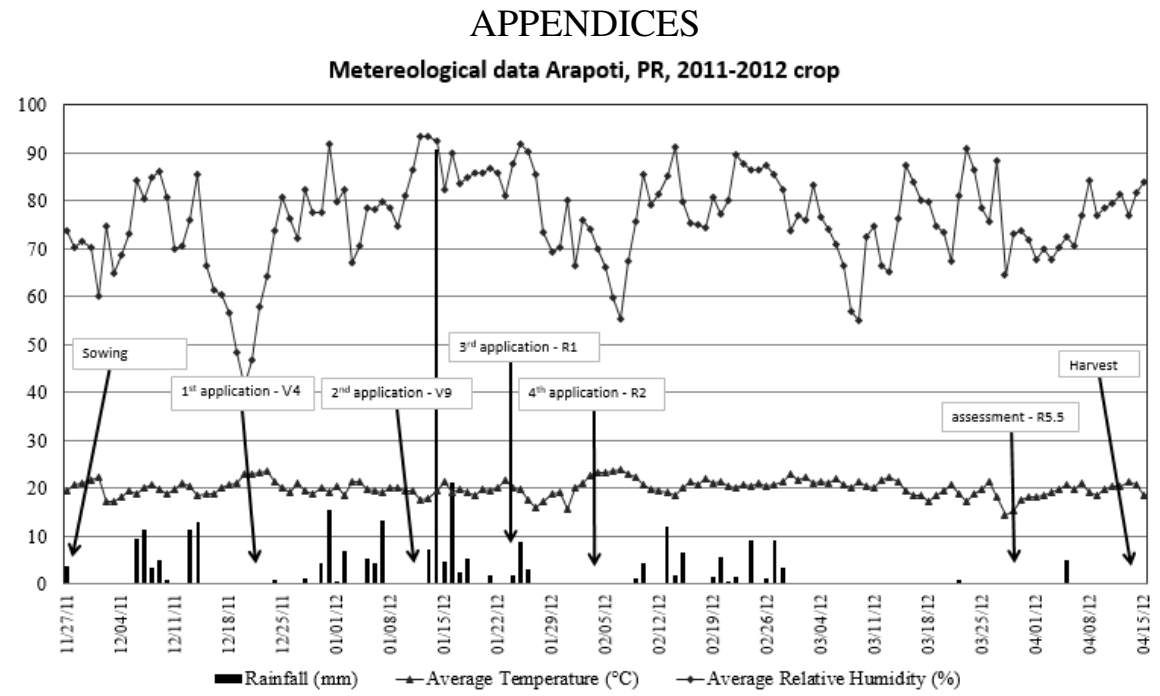

Appendix A. Meteorological data from experiment conducted in Arapoti, PR in 2011-2012 crop. V4: 4 trifoliate leaves open; V9: 9 trifoliate leaves open; R1: first open flower; R2: full bloom.

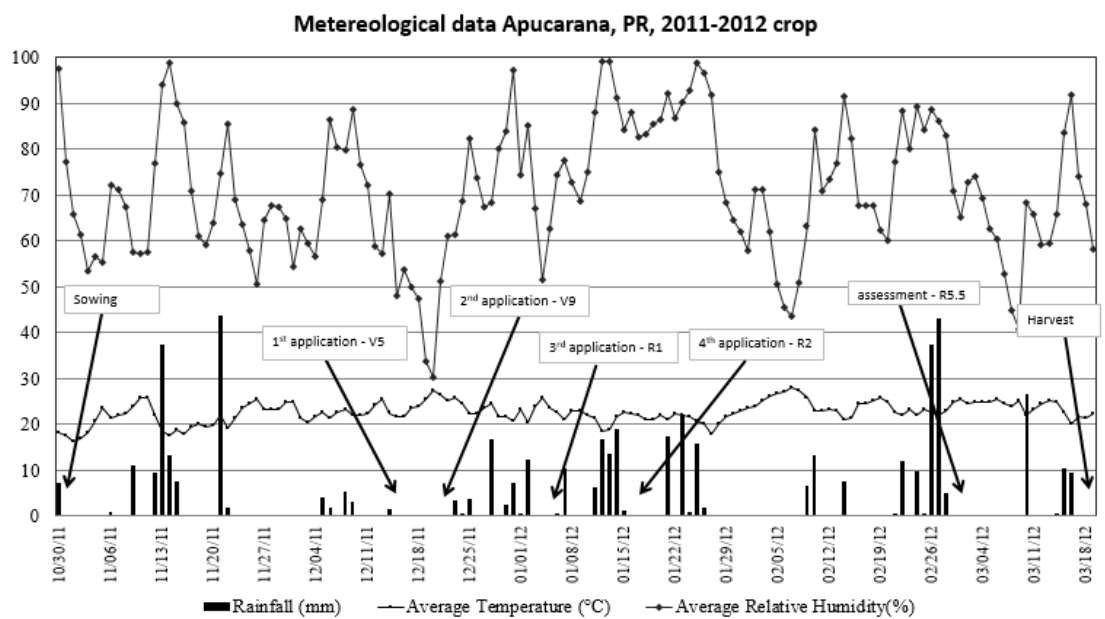

Appendix B. Meteorological data from Apucarana,PR, 2011-2012 crop, used as a reference for experiment conducted in Mauá-da-Serra, PR. Source: SIMEPAR. V5: 5 trifoliate leaves open; V9: 9 trifoliate leaves open; R1: first open flower; R2: full bloom.

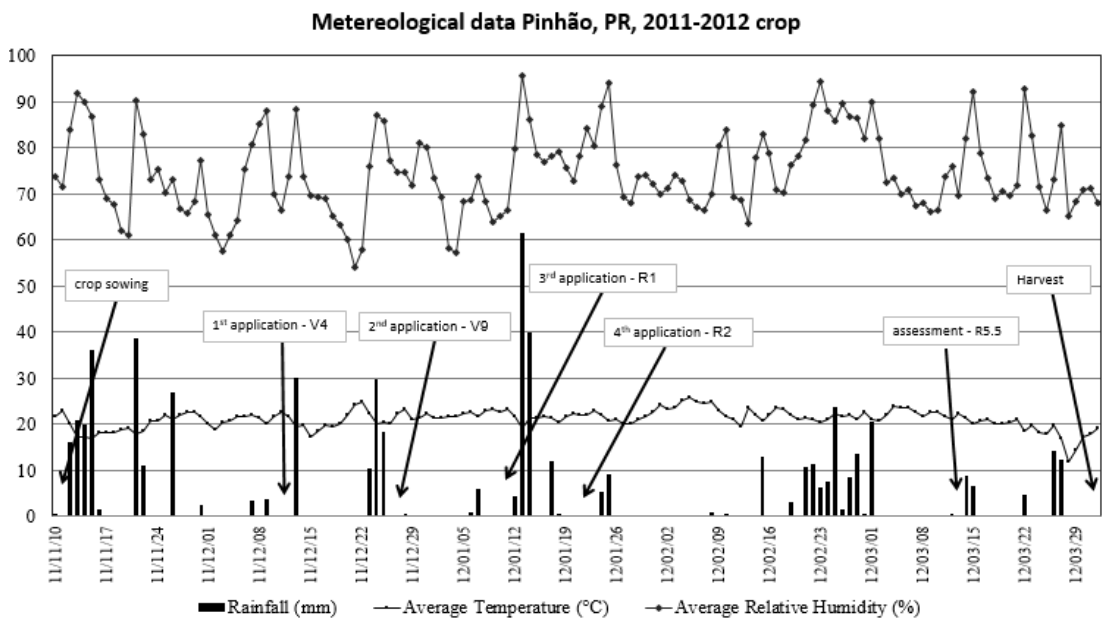

Appendix C. Meteorological data from the experiment conducted in Pinhão, PR, 2011-2012 crop. Source: SIMEPAR. V4: 4 trifoliate leaves open; V9: 9 trifoliate leaves open; R1: first open flower; R2: full bloom. 